\title{
POTENSI DIsINTEgRAsI DAN RAsa NAsIONALIsme MASYARAKAT KABUPATEN NATUNA
}

\section{NATIONALISM AND THE DISINTEGRATION POTENTIAL OFNATUNA PEOPLE}

\author{
Budiana Setiawan \\ Pusat Penelitian Kebijakan Pendidikan dan Kebudayaan \\ Kompleks Kementerian Pendidikan dan Kebudayaan, Gedung E, Lantai 19 \\ Jl. Jenderal Sudirman, Senayan, Jakarta, Indonesia \\ E-mail: budianasetiawan@gmail.com
}

DOI: 10.30959/patanjala.v11i3.526

\begin{abstract}
Abstrak
Kabupaten Natuna merupakan salah satu wilayah terluar dari Negara Kesatuan Republik Indonesia (NKRI), sehingga dianggap mempunyai potensi disintegrasi. Terlebih, Malaysia pernah mengklaim bahwa Natuna seharusnya masuk kedalam wilayahnya. Permasalahan dalam tulisan ini adalah: (1) Bagaimana rasa nasionalisme masyarakat Natuna? (2) Adakah potensi disintegrasi masyarakat Natuna, untuk memilih menjadi bagian dari Malaysia? (3) Bagaimana upaya pemerintah untuk menjaga Natuna agar tidak terlepas dari NKRI? Tujuan penelitian ini untuk mengetahui faktor-faktor yang menentukan rasa nasionalisme dan potensi disintegrasi masyarakat Natuna serta upaya pemerintah untuk menjaga Kabupaten Natuna sebagai wilayah kedaulatan NKRI. Penelitian ini bersifat kualitatif dengan teknik pengumpulan data melalui wawancara mendalam, observasi, dan studi pustaka. Hasil penelitian menunjukkan bahwa kedekatan geografis, ekonomi, dan sosial budaya dengan Malaysia, tidak menyebabkan rasa nasionalisme masyarakat Natuna rendah dan berkeinginan untuk disintegrasi. Meskipun demikian, apabila pemerintah kurang memperhatikan kesejahteraan masyarakat, potensi disintegrasi tersebut dapat meningkat.
\end{abstract}

Kata kunci: potensi, disintegrasi, nasionalisme.

\section{Abstract}

Natuna Regency is one of outermost areas of the Republic of Indonesia that is considered to have disintegration potential. Moreover, Malaysia once claimed that Natuna should have entered to its territory. The problems in this paper are: (1) What about spirit of nationalism of people in Natuna is that geographically, economically and socio-cultural are closer to Malaysia than Indonesia? (2) Is there a potential for Natuna people to disintegrate themselves and choose to become a part of Malaysia? (3) What is government's effort to protect Natuna from being separated from the Unitary State of the Republic of Indonesia? The aims of this paper are to gauge the factors that determine the sense of nationalism and potential disintegration of Natuna community and to estimate the government's efforts to safeguard it as a part of its territory. This paper is qualitative research with data collection techniques through in-depth interviews, observations, and literature studies. The results show that the geographical, economic and sociocultural proximity to Malaysia do not cause the Natuna people's nationalism to be waning or want to disintegrate. However, if the government does not pay attention to people's welfare, potential for disintegration can increased dramatically.

Keywords: potention, disintegration, nationalism. 


\section{A. PENDAhuluan}

Kepulauan terbesar di dunia dengan luas wilayah mencapai $5.176 .800 \mathrm{~km}^{2}$, terdiri atas luas lautan $3.257 .357 \mathrm{~km}^{2}$ dan daratan $1.919 .443 \mathrm{~km}^{2}$. Jumlah pulau di Indonesia mencapai 17.508 buah. ${ }^{1}$ Sebagai sebuah negara kepulauan, mobilitas penduduk antara pulau satu ke pulau lain dibatasi oleh lautan yang luas. Pulau-pulau yang secara geografis terletak di tengahtengah lautan luas dan jauh dari pusat pemerintahan, relatif sulit dijangkau dengan sarana transportasi, baik transportasi laut maupun udara. Hal ini berimplikasi pada kurangnya pemerataan pembangunan. Oleh karena itu menjaga keutuhan wilayah Negara Kesatuan Republik Indonesia (NKRI) sebagai negara kepulauan terbesar di dunia, dari mengendurnya rasa nasionalisme dan potensi disintegrasi menjadi permasalahan yang sulit diatasi. Ada anggapan bahwa potensi disintegrasi tersebut menjadi semakin menguat pada wilayah pulaupulau terdepan, terluar, dan tertinggal.

Lalu, apa yang dimaksud dengan nasionalisme dan disintegrasi? Berkaitan dengan nasionalisme, terdapat cukup banyak definisi mengenai nasionalisme. Beberapa di antaranya adalah John Hutchinson, Retno Listyarti, Cahyo Pamungkas, Ben Anderson, dan P. Nainggolan. Menurut John Hutchinson, nasionalisme adalah suatu paham atau ideologi untuk mencintai bangsa dan negara atas kesadaran warga negara yang secara potensial bersama-sama mencapai, mempertahankan, dan mengabdikan identitas, integritas, kemakmuran, dan kekuatan bangsanya. Menurutnya, nasionalisme lebih merupakan fenomena budaya daripada fenomena politik, karena nasionalisme tersebut berakar pada

1“Luas Wilayah Indonesia” dalam

https://www.scribd.com/doc/111362334/Luas-

Wilayah-Indonesia, diakses tanggal 27 Oktober 2018. etnisitas dan budaya pramodern (Hutchinson and Smith, 2000: 34).

Menurut Retno Listyarti, nasionalisme terdiri dari beberapa bentuk, yakni: nasionalisme kewarganegaraan, nasionalisme etnis, nasionalisme romantik, nasionalisme budaya, nasionalisme kenegaraan, dan nasionalisme agama. Pertama, nasionalisme kewarganegaraan (nasionalisme sipil), yakni negara memperoleh legitimasi politik dari partisipasi aktif rakyatnya dan keanggotaannya bersifat sukarela. Kedua, nasionalisme etnis (etnonasionalisme), yakni negara memperoleh legitimasi politik dari budaya asal atau etnis suatu masyarakat, dan keanggotaannya bersifat turun-temurun. Ketiga, nasionalisme romantik, yakni negara memperoleh legitimasi politik sebagai sesuatu yang alamiah dan merupakan ekspresi dari suatu bangsa atau ras. Nasionalisme romantik ini menitikberatkan pada budaya etnis yang sesuai dengan idealisme romantik mereka. Keempat, nasionalisme budaya, yakni negara memperoleh legitimasi politik dari budaya bersama dan tidak bersifat turuntemurun. Kelima, nasionalisme kenegaraan, yakni nasionalisme kewarganegaraan yang dikombinasikan dengan nasionalisme etnis. Dalam nasionalisme kenegaraan, sebuah bangsa adalah suatu komunitas yang memberikan kontribusi terhadap pemeliharaan dan kekuatan negara. Keenam, nasionalisme agama, yakni negara memperoleh legitimasi politik atas dasar persamaan agama (Listyarti, 2007:28).

Menurut Cahyo Pamungkas, konsep nasionalisme mencakup aspek kognitif, afektif, dan perilaku. Aspek kognitif ialah pengetahuan tentang Indonesia sebagai sebuah negara yang memiliki batas-batas geografis dan politik. Aspek afektif adalah perasaan sebagai warga bangsa Indonesia. Sementara itu, aspek perilaku adalah praktik-praktik menanamkan rasa nasionalisme dalam kehidupan sehari-hari yang dilakukan oleh negara. Dengan demikian nasionalisme yang didefinisikan 
oleh negara dapat dilihat dalam pengetahuan, perasaan, dan praktik-praktik pemeliharaan rasa kebangsaan. Namun, Cahyo Pamungkas juga menyatakan bahwa pemahaman dan praktik-praktik sosial yang dilakukan oleh warga perbatasan sering kali berbeda dengan semangat kebangsaan yang dikonstruksi oleh negara. Dengan demikian, masih ada kesenjangan antara wawasan kebangsaan dan makna kebangsaan yang direpresentasikan oleh praktik-praktik sosial dalam kehidupan sehari-hari masyarakat di daerah perbatasan (Pamungkas, 2015: 148).

$$
\text { Menurut Ben Anderson, }
$$
nasionalisme lebih dipahami sebagai komunitas politik terbayang. Artinya, nasionalisme tidak menemukan relevansi dan gagal dimaknai oleh masyarakat yang membayangkannya ketika dihadapkan dalam konteks ekonomi, politik, dan sosial budaya. Pemberian pendidikan wawasan kebangsaan sebagai upaya pemeliharaan rasa kebangsaan belumlah cukup untuk menanamkan rasa nasionalisme. Lebih dari itu, harus ada keadilan, kesejahteraan, dan kemakmuran bersama (Anderson, 1991).

Menurut P. Nainggolan, salah satu aspek nasionalisme adalah kebanggaan akan jati diri bangsa, yakni sejauh mana masyarakat yang hidup di perbatasan memiliki rasa bangga sebagai bangsa Indonesia (yang dalam terminologi Anderson dipahami sebagai "komunitas politik yang dibayangkan"). Kebanggaan nasional warga di daerah perbatasan muncul sebagai konsekuensi logis keberhasilan Negara menyelenggarakan pembangunan nasional untuk memenuhi kebutuhan masyarakat, terutama transportasi dan komunikasi. Kurangnya pemenuhan kesejahteraan dapat berimplikasi pada menurunnya kebanggaan nasional dan memberikan kemungkinan yang lebih besar terhadap menurunnya ketahanan dalam menjaga keberlangsungan negara bangsa (Nainggolan, 2004: 13).

Adapun disintegrasi menurut Kamus Besar Bahasa Indonesia adalah merupakan suatu keadaan tidak bersatu padu; keadaan terpecah belah; hilangnya keutuhan atau persatuan; perpecahan (Tim Penyusun Kamus Pusat Pembinaan dan Pengembangan Bahasa, 1990: 201). Menurut Endang Susilowati dan kawankawan, potensi disintegrasi pada wilayah pulau-pulau terdepan, terpencil, dan tertinggal adalah karena kurangnya perhatian pemerintah terhadap kesejahteraan penduduk di pulau-pulau tersebut. Oleh karena itu diperlukan kepekaan dari pemerintah untuk menyelesaikan isu-isu sosial ekonomi di pulau-pulau tersebut (Susilowati dkk., 2014: 158).

Salah satu wilayah yang dianggap mempunyai potensi disintegrasi adalah Kabupaten Natuna, Provinsi Kepulauan Riau. Kabupaten ini secara geografis merupakan salah satu wilayah terluar dari NKRI. Kabupaten Natuna juga merupakan kabupaten yang berjarak paling jauh dari Kota Tanjungpinang sebagai pusat pemerintahan Provinsi Kepulauan Riau, yakni mencapai $549 \mathrm{~km}$. Untuk mencapai wilayah kabupaten ini, harus menggunakan pesawat udara maupun kapal laut.

Wilayah kabupaten ini berupa gugusan kepulauan di tengah Laut Natuna Utara (dahulu disebut Laut Cina Selatan). Kepulauan Natuna telah dimasukkan kedalam wilayah Indonesia berdasarkan Surat Keputusan Delegasi RI, Provinsi Sumatera Tengah, pada tanggal 18 Mei 1956. Merunut sejarahnya, ternyata Malaysia pernah mengklaim bahwa Kepulauan Natuna seharusnya masuk kedalam wilayah mereka. Ada dua alasan yang digunakan Malaysia untuk mengklaim wilayah Kepulauan Natuna. Pertama, secara geografis wilayah Kepulauan Natuna "terjepit" di antara Malaysia bagian barat (Semenanjung Malaysia) dan Malaysia bagian timur (Sabah dan Sarawak di bagian utara Pulau Kalimantan). Bila ditarik garis lurus pada ujung selatan Semenanjung Malaysia dan Sarawak, maka Kepulauan Natuna seharusnya menjadi wilayah Malaysia. 
Kedua, berdasarkan sejarah, sejak tahun 1597 Kepulauan Natuna termasuk dalam wilayah Kesultanan Johor, salah satu kesultanan yang pada saat ini menjadi bagian dari wilayah Malaysia. Dengan demikian, baik secara geografis maupun sejarah, masyarakat Kabupaten Natuna memiliki kedekatan dengan Malaysia daripada Indonesia (Wawancara dengan Amiruddin, 18 November 2017).

Meskipun demikian, klaim Malaysia tersebut tidak pernah benar-benar menjadi isu hangat, yang menyebabkan terjadinya konflik perebutan wilayah kekuasaan antara Indonesia dengan Malaysia. Masyarakat di Kabupaten Natuna pun belum pernah secara terbuka menghembuskan isu ingin melepaskan diri dari Indonesia dan bergabung dengan Malaysia. Padahal sebagai wilayah yang secara geografis lebih dekat dengan Malaysia dan secara historis mempunyai keterkaitan sejarah dengan Kesultanan Johor, pada masa lalu pengaruh ekonomi dan sosial-budaya dari Malaysia lebih terasa daripada Indonesia.

Tujuan dari tulisan ini adalah, pertama untuk mengetahui faktor-faktor yang menentukan rasa nasionalisme masyarakat di Kabupaten Natuna lebih kuat kepada Indonesia daripada Malaysia. Kedua, untuk memperoleh gambaran ada atau tidaknya potensi disintegrasi masyarakat Kabupaten Natuna. Ketiga, mengetahui upaya pemerintah untuk menjaga Kabupaten Natuna sebagai wilayah kedaulatan NKRI.

Berdasarkan pemaparan tersebut di atas, permasalahan yang diangkat dalam tulisan ini adalah sebagai berikut. Pertama, bagaimana rasa nasionalisme masyarakat Kabupaten Natuna yang secara yuridis maupun administratif menjadi bagian dari wilayah NKRI, namun secara geografis, ekonomi, dan sosial budaya lebih dekat dengan Malaysia? Kedua, apakah ada potensi disintegrasi masyarakat Kabupaten Natuna, untuk kemudian memilih menjadi bagian dari wilayah Negara Malaysia? Ketiga, bagaimana upaya pemerintah untuk menjaga Kabupaten Natuna agar tidak terlepas dari wilayah kedaulatan NKRI?

\section{B. METODE PENELITIAN}

Penelitian ini merupakan jenis penelitian kualitatif. Penelitian kualitatif adalah penelitian untuk memahami dan menganalisis kehidupan sosial dengan cara menggambarkan dunia sosial dari sudut pandang atau interpretasi narasumber/ masyarakat yang diteliti dalam latar alamiah. Dengan kata lain, penelitian kualitatif berusaha menjelaskan bagaimana para narasumber/ masyarakat yang diteliti tersebut melihat, menggambarkan, atau memaknai dunia sosialnya (Martono, 2016: 212). Teknik pengumpulan data yang dilakukan dalam penelitian ini, meliputi: wawancara mendalam, pengamatan/ observasi, dan studi pustaka.

Pengamatan atau observasi
dilakukan dengan tujuan untuk mencatat berbagai hal yang penting berkaitan dengan tujuan penelitian, seperti: kondisi geografis, kehidupan sosial budaya masyarakat, interaksi antarkomunitas, dan lain-lain (Bachtiar, 1997: 108-119). Dalam hal ini observasi dilakukan di Kota Ranai, ibukota Kabupaten Natuna. Dalam pengamatan tersebut dilakukan pendokumentasian tentang kondisi masyarakat, aksesibilitas menuju lokasi, fasilitas yang disediakan pemerintah, dan lain-lain.

Dalam wawancara mendalam, teknik mencari informan adalah dengan menarik jaringan interkoneksi individu atau organisasi di lokasi penelitian. Wawancara mendalam dilakukan untuk mendapatkan data primer dari para informan/ narasumber tersebut (Neuman, 2006: 222223). Dalam hal ini beberapa informan yang dapat ditemui di lapangan, antara lain aparatur dari Sekolah Tinggi Agama Islam Natuna, dan unsur-unsur aparatur pemerintahan; Dinas Perikanan, Kantor Badan Karantina Laut dan Penjaminan Mutu; Dinas Pendidikan; dan lain-lain. 
Untuk memperkaya data yang diperoleh di lapangan, dilakukan pula studi pustaka, baik sebelum maupun setelah penelitian di lapangan. Sebelum melakukan penelitian di lapangan, dilakukan studi pustaka terlebih dahulu. Dalam studi pustaka ini penulis mencari dan menelaah tulisan-tulisan dan artikelartikel yang relevan dengan permasalahan penelitian. Data yang diperoleh dari pengamatan, wawancara mendalam, FGD, dan studi kepustakaan tersebut kemudian dianalisis dengan beberapa konsep yang relevan dengan permasalahan yang diangkat dalam tulisan ini (Creswell, 1994: 18).

\section{HASIL DAN BAHASAN \\ 1. Gambaran Singkat Kabupaten Natuna}

Kabupaten Natuna secara astronomis terletak pada posisi $01^{\circ} 18^{\prime} 00^{\prime \prime}-06^{\circ} 50^{\prime}$ $15^{\prime \prime}$ Lintang Utara dan $104^{\circ} 48^{\prime} 30^{\prime \prime}-110^{\circ}$ 02' 00" Bujur Timur. Secara administratif sebelah utara berbatasan dengan Laut Natuna, sebelah timur dengan Laut Natuna, sebelah selatan dengan Kabupaten Bintan (Provinsi Kepulauan Riau), dan sebelah barat dengan Semenanjung Malaysia (Kabupaten Natun adalam Angka 2017: 3).

Luas wilayah Kabupaten Natuna secara keseluruhan mencapai 224.684,59 $\mathrm{km}^{2}$, terdiri dari luas daratan $2.001,3 \mathrm{~km}^{2}$ dan luas lautan 222.683,29 $\mathrm{km}^{2}$. Dengan demikian, luas daratan kabupaten ini hanya $0,9 \%$ dari seluruh luas wilayahnya. Sebagai sebuah daerah kepulauan, kabupaten ini memiliki 154 pulau, di mana hanya 27 pulau $(17,53 \%)$ yang berpenghuni, sedangkan 127 pulau lainnya $(82,44 \%)$ tidak berpenghuni. Pulau-pulau tersebut dikelompokkan dalam dua gugusan, yakni Gugusan Pulau Natuna (terdiri atas Pulau Bunguran, Sedanau, Midai, Pulau Laut, dan Pulau Tiga) dan Gugusan Pulau Serasan (terdiri atas pulaupulau di Serasan, Subi Besar, dan Subi Kecil) (Kabupaten Natuna dalam Angka 2017: 7-8). Di antara pulau-pulau tersebut,
Pulau Bunguran adalah pulau yang terbesar, dengan luas mencapai 1,259,87 $\mathrm{km}^{2}$ atau $62,95 \%$ dari keseluruhan luas daratan. Penduduk Kabupaten Natuna berdasarkan sensus tahun 2016 sebanyak 75.282 jiwa, terdiri atas 38.826 laki-laki dan 36.456 perempuan. Tingkat kepadatan penduduk mencapai 38 jiwa per $\mathrm{km}^{2}$ (Kabupaten Natuna dalam Angka 2017: 63).

Kabupaten Natuna pada awalnya merupakan bagian dari Kabupaten Kepulauan Riau, Provinsi Riau. Pada tanggal 12 Oktober 1999, berdasarkan Undang-Undang Nomor 53 tahun 1999 tentang Pembentukan Kabupaten Pelalawan, Kabupaten Rohan Hulu, Kabupaten Siak, Kabupaten Karimun, Kabupaten Natuna, Kabupaten Kuantan Singingi, dan Kota Batam, maka Kepulauan Natuna disahkan sebagai kabupaten tersendiri, yang merupakan pemekaran dari Kabupaten Kepulauan Riau, dengan wilayah meliputi gugusan Kepulauan Natuna dan Kepulauan Anambas. ${ }^{2}$ Kemudian pada tanggal 31 Juli 2008, berdasarkan Undang-Undang Nomor 33 tahun 2008 tentang Pembentukan Kabupaten Kepulauan Anambas di Provinsi Kepulauan Riau, maka dibentuk kabupaten baru hasil pemekaran dari Kabupaten Natuna, yakni Kabupaten Kepulauan Anambas, dengan wilayah gugusan Kepulauan Anambas yang terletak di sebelah barat daya gugusan Kepulauan Natuna (Nuraini,2008).

\footnotetext{
${ }^{2}$ Adapun Provinsi Kepulauan Riau sendiri baru terbentuk pada tanggal 24 September 2002 berdasarkan Undang-Undang Nomor 25 Tahun 2002 tentang Pembentukan Provinsi Kepulauan Riau. Provinsi baru ini meliputi 5 kabupaten dan 2 kota, yakni: Kota Tanjungpinang, Kota Batam, Kabupaten Bintan, Kabupaten Karimun, Kabupaten Natuna, Kabupaten Kepulauan Anambas, dan KabupatenLingga.
} 


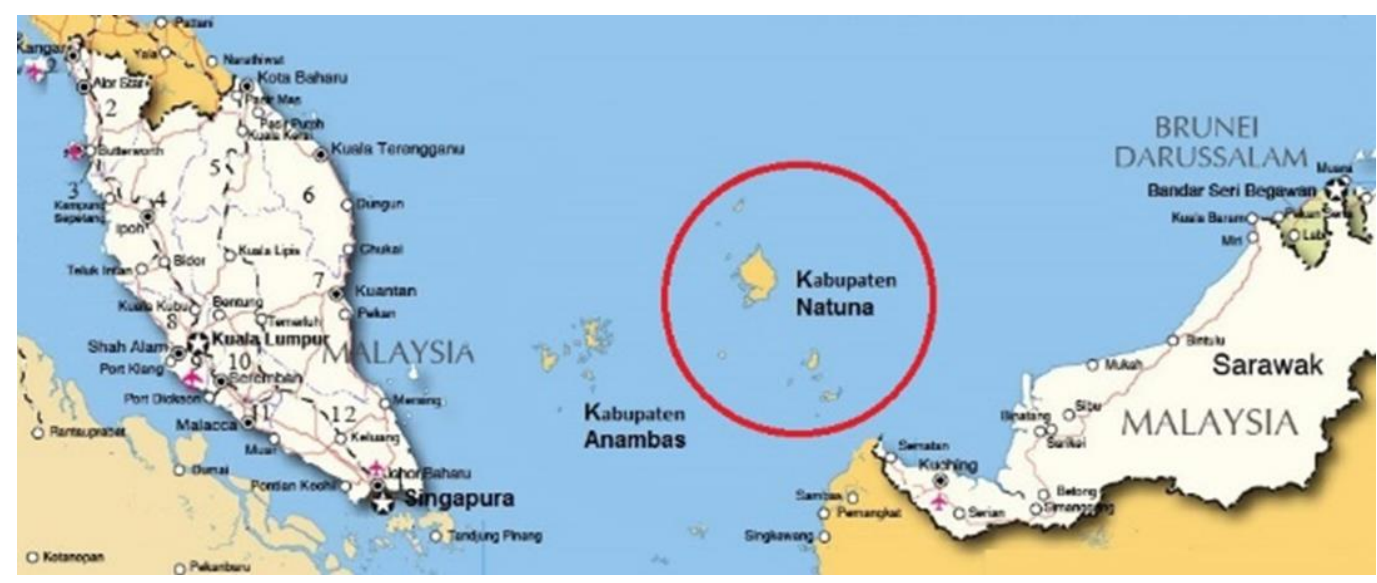

Gambar 1. Kabupaten Natuna, yang "diapit” Malaysia bagian barat dan bagian timur. Sumber: Peta Malaysia. https://www. romadecade.org/peta-malaysia/\#! Diunduh 27 Oktober 2018.

\section{Natuna dalam Perjalanan Sejarah}

Sejak dahulu Kepulauan Natuna menjadi wilayah yang strategis untuk diperebutkan oleh banyak kerajaan, karena menjadi jalur pelayaran perdagangan yang ramai. Pada tahun 1597 wilayah Kepulauan Natuna masuk dalam wilayah kekuasaan Kerajaan Pattani (saat ini masuk wilayah Thailand) dan Kesultanan Johor (saat ini masuk wilayah Malaysia). Namun pada abad XIX Kepulauan Natuna masuk dalam wilayah kekuasaan Kesultanan Riau. Setelah berdirinya Republik Indonesia pada tahun 1945, delegasi dari Kesultanan Riau ikut menyerahkan kedaulatannya pada Republik Indonesia. Dikarenakan wilayah Kepulauan Natuna pada saat itu berada dalam kekuasaan Kesultanan Riau, maka juga dianggap sebagai bagian dari wilayah kedaulatan Republik Indonesia (Tampi, 2017: 4).

Adapun dalam Traktat London pada tahun 1824, yang merupakan perjanjian antara Inggris dengan Belanda tentang pembagian wilayah jajahan, tidak secara tegas memasukkan Kepulauan Natuna kedalam wilayah jajahan Inggris maupun Belanda. Dengan demikian, Natuna menjadi bagian dari wilayah Indonesia tersebut bukan didasarkan pada Traktat London (Susilowati dkk. 2014: 163). Ada kemungkinan, klaim atas Natuna tersebut atas dasar pertimbangan bahwa wilayah Natuna pada saat Proklamasi Kemerdekaan RI tahun 1945, masuk dalam wilayah Kesultanan Riau. Oleh karena itu, maka wilayah Natuna diklaim oleh Pemerintah Indonesia masuk dalam wilayah Indonesia. Klaim Pemerintah Republik Indonesia terhadap wilayah Kepulauan Natuna menimbulkan perselisihan dengan Malaysia. Malaysia menyatakan bahwa Kepulauan Natuna seharusnya menjadi milik Malaysia. Ada dua alasan yang digunakan Malaysia untuk mengklaim wilayah Kepulauan Natuna. Pertama, berdasarkan sejarah, sejak tahun 1597 Kepulauan Natuna termasuk dalam wilayah Kesultanan Johor, salah satu kesultanan yang pada saat ini menjadi bagian dari wilayah Malaysia. Kedua, secara geografis wilayah Kepulauan Natuna "terjepit" di antara Malaysia bagian barat (Semenanjung Malaysia) dan Malaysia bagian timur (Sabah dan Sarawak di bagian utara Pulau Kalimantan). Bila ditarik garis lurus pada ujung selatan Semenanjung Malaysia dan Sarawak, maka Kepulauan Natuna seharusnya menjadi wilayah Malaysia. Dengan demikian, baik secara geografis maupun sejarah, masyarakat Kabupaten 
Natuna memiliki kedekatan dengan Malaysia daripada Indonesia. ${ }^{3}$

Malaysia juga menganggap bahwa Traktat London pada tahun 1824 tidak dapat digunakan sebagai dasar hokum penguasaan Republik Indonesia atas wilayah Kepulauan Natuna, karena wilayah tersebut tidak pernah benar-benar dikuasai Belanda, seperti halnya Pulau Jawa, Sumatera, Sulawesi, dan pulau-pulau lainnya di Indonesia. Menurut Susilowati dan kawan-kawan, di wilayah Natuna juga tidak ditemukan satu pun mercusuar peninggalan Belanda atau Inggris yang dapat digunakan untuk membuktikan bahwa wilayah ini adalah wilayah Hindia Belanda ataupun Inggris (Susilowati, dkk. 2014: 163). Menurut Malaysia, Traktat London tidak menempatkan Kepulauan Natuna di bawah kekuasaan Inggris maupun Belanda, tetapi di bawah kekuasaan Kesultanan Melayu Johor yang pada waktu itu sudah di bawah pengaruh Inggris. Kesultanan Johor merdeka dari Inggris pada tahun 1957 dan bergabung menjadi wilayah persekutuan Malaysia. Atas dasar hal tersebut, Malaysia akhirnya menyimpulkan bahwa sesuai dengan konsep"utipossidetis juris", $^{4}$ maka Kepulauan Natuna yang merupakan wilayah Kesultanan Johor seharusnya menjadi bagian dari Malaysia. Dengan kata lain, karena Kepulauan Natuna tidak pernah menjadi daerah jajahan Belanda,

\footnotetext{
${ }^{3}$ Kamal, Mustafa. 2014. "Malaysia Inginkan Kepulauan Natuna Menjadi Wilayahnya." dalam https://www.kompasiana.com/alchemist/malays ia-inginkan-kep-natuna-menjadi-wilayahnya_ 54f7bc7ba333112b6f8b4cc7, diakses tanggal 27 November 2017

${ }^{4}$ Uttipossidetis juris adalah konsep untuk menetapkan batas-batas negara yang baru saja merdeka dari penjajahnya dengan memastikan bahwa perbatasan tersebut mengikuti batasbatas wilayah kolonial lama (Hensel, Allison, and Khanani, 2006).
}

maka seharusnya daerah tersebut bukan bagian dari Indonesia. ${ }^{5}$

Sebaliknya, Indonesia mengklaim wilayah Kepulauan Natuna sebagai bagian dari wilayahnya karena menganggap ada bukti jejak-jejak kekuasaan Belanda di kepulauan tersebut. Salah satu di antaranya adalah keberadaan lapangan udara di Pulau Subi yang sebenarnya dibangun oleh Pemerintah Kolonial Jepang pada saat menduduki Indonesia pada 1942. Ketika Jepang kalah dalam Perang Dunia II, lapangan udara tersebut dibombardir dan diambilalih oleh pasukan Belanda. ${ }^{6}$ Penyerangan Belanda atas lapangan udara yang dibangun oleh Pemerintah Jepang inilah yang merupakan "satu-satunya bukti" kekuasaan Belanda di Natuna.

Untuk memperkuat kedaulatannya di wilayah Natuna, pada 18 Mei 1956 Pemerintah Republik Indonesia secara resmi mendaftarkan Kepulauan Natuna ke Perserikatan Bangsa-Bangsa. Pada tahun 1962-1966 terjadi konfrontasi antara Indonesia dengan Malaysia. Dalam konfrontasi tersebut, Kepulauan Natuna menjadi wilayah yang dipersengketakan oleh kedua negara. Konfrontasi tersebut secara politik lebih merugikan Malaysia dari pada Indonesia, sehingga untuk menghindari konflik yang berkepanjangan, maka Malaysia memilih tidak menggugat status dari Kepulauan Natuna (Tampi, 2017: 4). Malaysia pun memilih jalan damai dan membiarkan Kepulauan Natuna menjadi bagian dari wilayah Indonesia.

\footnotetext{
${ }^{5}$ Kamal, Mustafa. 2014. "Malaysia Inginkan Kepulauan Natuna Menjadi Wilayahnya.“ dalam https://www.kompasiana.com/alchemist/malays ia-inginkan-kep-natuna-menjadi-wilayahnya_ $54 f 7 b c 7 b a 333112 b 6 f 8 b 4 c c 7$, diakses tanggal 27 November 2017.

${ }^{6}$ Yuri B.Trisna. "PulauSubi, Pusat Pertahanan Udara Jepang di Natuna" dalam https://pelantar.id/berita/kepriraya/natuna/pulau-subi-pusat-pertahananudara-jepang-di-natuna/, diakses 25 Februari 2019.
} 
Hingga saat ini pun Malaysia tidak pernah mengotak-atik lagi keberadaan Kepulauan Natuna. Hal ini berarti Malaysia telah mengakui kedaulatan Indonesia atas Kepulauan Natuna. ${ }^{7}$

\section{Kehidupan Ekonomi, Sosial, Budaya Masyarakat Kabupaten Natuna}

Meskipun menjadi bagian dari wilayah Indonesia, namun interaksi dalam bidang ekonomi dan sosial-budaya masyarakat Natuna lebih dekat dengan Malaysia dari pada Indonesia.Terlebih pada masa lalu, di mana jaringan telekomunikasi dan transportasi ke Natuna belum sepenuhnya tekoneksi. Di bidang ekonomi, masyarakat Natuna telah sejak lama menjalin hubungan perdagangan dengan masyarakat Sarawak, Malaysia bagian timur. Hal ini dikarenakan secara geografis Kabupaten Natuna lebih dekat dengan Kota Kuching, ibukota Negara Bagian Sarawak, Malaysia (dengan jarak sekitar $350 \mathrm{~km}$ ) dibandingkan dengan Kota Tanjungpinang, ibukota Provinsi Kepulauan Riau (yang berjarak sekitar 545 km) (Susilowati dkk. 2014: 159).

Banyak barang kebutuhan seharihari yang didatangkan dari Kota Kuching, Sarawak. Sebaliknya, masyarakat Natuna juga menjual komoditas perkebunan dan perikanan kepada para pedagang dari Sarawak. Hal ini menyebabkan di Natuna banyak ditemukan produk-produk dari Sarawak.

Bahkan sebelum tahun 1960-an masyarakat Natuna juga masih menggunakan mata uang ringgit. Mata uang rupiah baru dikenalkan setelah terjadi Konfrontasi Indonesia-Malaysia pada

\footnotetext{
${ }^{7}$ Kamal, Mustafa. 2014. "Malaysia Inginkan Kepulauan Natuna Menjadi Wilayahnya.“ dalam

https://www.kompasiana.com/alchemist/malays ia-inginkan-kep-natuna-menjadi-wilayahnya 54f7bc7ba333112b6f8b4cc7, diakses tanggal 27 November 2017.
}

tahun 1962-1966. ${ }^{8}$ Meskipun demikian, mata uang ringgit tidak serta-merta hilang, sehingga pada saat itu masyarakat Natuna menggunakan ringgit dan rupiah sekaligus. Kondisi ini berlangsung bertahun-tahun, hingga tahun 2000 (Wawancara dengan Amiruddin, 18 November 2017).

Kedekatan jarak antara Kabupaten Natuna dengan Sarawak menyebabkan harga barang-barang kebutuhan sehari-hari dari Sarawak lebih murah dibandingkan dengan barang-barang yang didatangkan dari Batam ataupun Tanjungpinang. Hal ini disebabkan oleh jaraknya yang cukup jauh dan sarana transportasi yang kurang memadai. Sarana transportasi laut hanya dilayani oleh kapal perintis yang datang ke Pelabuhan Ranai setiap 13 hari sekali, sehingga barang-barang kebutuhan seharihari tidak selalu tersedia. Sementara kapalkapal dagang dari Sarawak datang hampir setiap hari, sehingga barang-barang dari Sarawak selalu tersedia dengan harga yang terjangkau (Susilawati dan Masruroh, 2018: 17).

Di bidang sosial budaya, berdasarkan etnisitasnya, mayoritas penduduk Kabupaten Natuna adalah etnis Melayu, kemudian diikuti Jawa sekitar $6,34 \%$ dan Tionghoa sekitar 2,52\% (Tampi, 2017: 4). Masyarakat Natuna berbicara dengan bahasa Melayu dialek Malaysia. Sejak puluhan tahun lamanya, masyarakat Natuna juga hanya

\footnotetext{
${ }^{8}$ Konfrontasi Indonesia-Malaysia adalah sebuah konflik memperebutkan wilayah Malaya, Brunei, Sabah, dan Sarawak, antara Federasi Malaysia dengan Indonesia. Konflik itu berlangsung tahun 1962 hingga 1966. Konflik berawal dari keinginan Federasi Malaysia untuk menggabungkan Brunei, Sabah, dan Sarawak kedalam Federasi Malaysia, yang oleh Indonesia dianggap tidak sesuai dengan Persetujuan Manila. Presiden Sukarno menganggap pembentukan Federasi Malaysia tersebut sebagai "boneka Inggris" dan merupakan kolonialisme dan imperialisme bentuk baru. (Witton, 2003: 28, 944; Mezerik, 1965: 8, 122).
} 
mendapatkan informasi melalui siaran radio dan televisi dari Malaysia, sehingga tidak mengherankan bila mereka lebih mengetahui peristiwa-peristiwa yang terjadi di Malaysia daripada di Indonesia. Baru pada tahun 1983 mereka mulai dapat menikmati siaran radio dan televisi dari Indonesia. Mobilitas masyarakat Natuna ke wilayah Indonesia lainnya juga terbatas, karena satu-satunya alat transportasi yang tersedia pada saat itu hanya kapal laut. Jalur pelayaran, khususnya yang menuju Batam dan Tanjungpinang sering terhenti karena sering terjadinya gelombang besar di Laut Natuna Utara (Wawancara dengan Arrofik, 19 November 2017).

\section{Nasionalisme Masyarakat Natuna}

Menilik perjalanan sejarah masyarakat Natuna, yang pernah menjadi bagian dari wilayah Kesultanan Johor, wilayah Kesultanan Riau, sebentar di bawah kekuasaan Jepang, dan akhirnya menjadi bagian dari wilayah Indonesia, serta kehidupan ekonomi, sosial, dan budaya masyarakatnya yang lebih dekat dengan Malaysia daripada Indonesia, tentu menimbulkan pertanyaan, bagaimana dengan rasa nasionalisme mereka? Terlebih lagi kedekatan letak geografis Natuna dengan Malaysia, kemudahan untuk memperoleh barang-barang kebutuhan sehari-hari, dan banyaknya informasi yang diperoleh dari Malaysia daripada Indonesia, bukan tidak mungkin akan membawa konsekuensi melemahnya nasionalisme penduduk Natuna. Hal itu masih ditambah dengan kenyataan bahwa pembangunan yang dicanangkan pemerintah pusat belum banyak menyentuh pulau-pulau terdepan, termasuk wilayah Kepulauan Natuna. Keadaan infrastruktur dan suprastruktur di beranda terdepan Indonesia itu masih jauh tertinggal dari daerah-daerah lain, terutama Jawa. Bila rasa nasionalisme penduduk tidak dibentengi dengan baik, tidak mustahil dapat mengancam integrasi nasional (Susilowati dkk, 2014: 159).
Namun hal yang menarik, kondisi tersebut di atas tidak menjadikan masyarakat Natuna menginginkan bergabung dengan Malaysia. Mereka tampaknya tidak terlalu mempedulikan, apakah keberadaan mereka menjadi bagian dari warga negara Indonesia ataupun Malaysia. Sekalipun secara geografis lebih dekat dengan Malaysia, mereka tidak pernah melakukan upaya untuk melepaskan diri dari Indonesia dan bergabung dengan Malaysia. Hal ini tampaknya dipengaruhi oleh cara pandang mereka terhadap kedua negara tersebut. Bagi mereka, Indonesia adalah sebuah negara besar, dengan wilayah yang jauh lebih luas dan jumlah penduduk yang jauh lebih besar daripada Malaysia. Di samping itu, masyarakat Natuna lebih melihat nama besar Indonesia dibandingkan dengan Malaysia, karena menjadi salah satu negara yang mempelopori kemerdekaan bagi negara-negara jajahan di kawasan Asia. Pada masa-masa awal kemerdekaan kedua negara tersebut, Indonesia menjadi negara yang lebih disegani oleh negara-negara di kawasan Asia dibandingkan dengan Malaysia.Ini yang tampaknya menjadi daya tarik bagi masyarakat Natuna untuk tetap memilih menjadi bagian dari Indonesia (Wawancara dengan Amiruddin, 18 November 2017).

Masyarakat Natuna juga tampaknya tidak terlalu memikirkan sejarah masa lalu yang pernah menjadi bagian dari Kesultanan Johor maupun Kesultanan Riau. Dalam hal ini,meskipun pernah dikuasai Kesultanan Johor (yang sekarang masuk dalam wilayah Malaysia) dan Kesultanan Riau (yang sekarang masuk dalam wilayah Indonesia), masyarakat Natuna tampaknya "tidak terlalu terikat secara emosional" dengan keduanya. Hal ini karena wilayahnya yang jauh terpisah oleh lautan, baik dengan pusat Kesultanan Johor maupun Kesultanan Riau. Dengan demikian, nasionalisme pada masyarakat Natuna lebih merupakan fenomena budaya dari pada fenomena politik, sebagaimana disampaikan oleh John Hutchinson (2004). 
Nasionalisme itu lebih bersifat cair, karena berakar dari sejarah maupun etnisitas Kemelayuan, yang dipengaruhi oleh kedua kesultanan tersebut.

Sebagaimana disampaikan oleh Retno Listyarti, bahwa nasionalisme terdiri dari enam bentuk, yakni: nasionalisme kewarganegaraan, nasionalisme etnis, nasionalisme romantik, nasionalisme budaya, nasionalisme kenegaraan, dan nasionalisme agama (Listiyarti, 2007: 28). Dari keenam bentuk nasionalisme tersebut, tampaknya yang sesuai untuk diterapkan pada masyarakat Natuna pada khususnya dan bangsa Indonesia pada khususnya adalah nasionalisme kenegaraan, yang merupakan kombinasi antara kewarganegaraan dengan etnisitas. Dalam hal ini secara kewarganegaraan, masyarakat Natuna secara legitimasi politik adalah bagian dari warga negara Indonesia. Secara etnisitas, sebagian besar masyarakat Natuna adalah etnis Melayu. Dalam hal ini etnis Melayu tidak hanya terdapat di satu negara, melainkan tersebar beberapa negara, yakni: Indonesia, Malaysia, Singapura, dan Brunei Darussalam. Dengan demikian, masyarakat Natuna secara alamiah mempunyai ikatan etnisitas dengan masyarakat Melayu yang tinggal di wilayah Indonesia, terutama dengan masyarakat Melayu di Kepulauan Riau, pesisir timur Sumatera, dan pesisir barat Kalimantan.

\section{Pembangunan untuk Penguatan Rasa Nasionalisme}

Meskipun pada dasarnya masyarakat Natuna tidak terlalu mempedulikan, apakah menjadi bagian dari warga negara Indonesia ataupun Malaysia, namun apabila perhatian pemerintah terhadap kesejahteraan mereka kurang, maka potensi disintegrasi tersebut suatu saat dapat muncul. Hal ini sesuai dengan yang disampaikan oleh Susilowati dan kawankawan, bahwa potensi disintegrasi pada wilayah pulau-pulau terdepan, terpencil, dan tertinggal apabila pemerintah tidak mampu menyelesaikan isu-isu sosial ekonomi di pulau-pulau tersebut (Susilowati dkk., 2014: 158).

Berkaitan dengan keberadaan pulaupulau terluar yang berbatasan dengan negara-negara lain, Pemerintah Indonesia telah mengeluarkan Peraturan Presiden Republik Indonesia Nomor 78 tahun 2005 tentang Pengelolaan Pulau-Pulau Kecil Terluar. Adapun tujuan dari pengelolaan pulau-pulau kecil terluar tertuang dalam Pasal 2, yakni:

a. Menjaga keutuhan wilayah Negara kesatuan Republik Indonesia, keamanan nasional, pertahanan Negara dan bangsa serta menciptakan stabilitas kawasan;

b. Memanfaatkan sumber daya alam dalam rangka pembangunan yang berkelanjutan, dan;

c. Memberdayakan masyarakat dalam rangka peningkatan kesejahteraan (Tampi, 2017: 4).

Berkaitan dengan hal tersebut, penguatan rasa nasionalisme sebagai bagian dari bangsa Indonesia mustahil dapat ditumbuhkan pada masyarakat Natuna selama pemerintah pusat tidak pernah memberikan perhatian dan pembangunan pada mereka sebagai masyarakat yang tinggal di daerah terluar. Namun dalam kenyataannya, meskipun telah menjadi bagian dari wilayah Indonesia sejak tahun 1956, selama berpuluh-puluh tahun tidak ada pembangunan yang signifikan di wilayah Kepulauan Natuna. Pembangunan secara besar-besaran baru mulai terjadi pada beberapa tahun belakangan ini. Hal ini sesuai dengan program Nawacita dari pemerintahan Presiden Joko Widodo dan Wakil Presiden Jusuf Kalla. Setidaknya terdapat lima kementerian yang diprioritaskan untuk menangani pembangunan di Kabupaten Natuna, yakni: Perikanan dan Kelautan, Pertahanan dan Keamanan, Pariwisata, Lingkungan Hidup 
dan Kehutanan, dan Energi dan Sumber Daya Mineral. ${ }^{9}$

Pembangunan yang ditangani oleh Kementerian Perikanan dan Kelautan dilakukan dengan pertimbangan bahwa Kepulauan Natuna memiliki wilayah laut yang sangat luas, dengan potensi sumber daya ikan yang sangat melimpah, namun teknologi penangkapan dan pengelolaan ikan yang dilakukan para nelayan di Kepulauan Natuna belum mampu mengakomodir potensi tersebut. Untuk itu Kementerian Kelautan dan Perikanan membangun Sentra Kelautan dan PerikananTerpadu (SKPT) di Selat Lampa, Kecamatan Natuna Utara, seluas 16,8 hektar. SKPT ini digunakan untuk menampung ikan dari Wilayah Pengelolaan Perikanan (WPP) 711, yang meliputi wilayah Selat Karimata, Laut Natuna, dan Laut Natuna Utara. Pembangunan SKPT ini didasarkan pada pertimbangan bahwa sumber daya perikanan Laut Natuna mencapai 1,2 juta ton per tahun. ${ }^{10} \mathrm{Di}$ sisilain, Laut Natuna juga menjadi jalur pelayaran internasional, sehingga potensi perikanannya rawan dicuri oleh kapal-kapal nelayan asing. Pembangunan SKPT di Selat Lampa ini dilakukan oleh Kementerian Kelautan dan Perikanan bersama Pemerintah Kabupaten Natuna untuk mendukung kesejahteraan masyarakat Natuna. ${ }^{11}$

${ }^{9}$ Vero, Adit. "Bupati Natuna Memakai Program Lima Pilar dalam Percepatan Pembangunan Daerahnya" dalam https://www. wartakepri.co.id/2018/01/24/bupati-natunamemakai-program-lima-pilar-dalam-

percepatan-pembangunan-daerahnyal, diakses tanggal 18 Februari 2019.

${ }^{10}$ Widjaja, Sjarief. "Pengembangan Perikanan: Bangun Ekonomi Maritim dari Natuna" dalam https:// kalimantan.bisnis. com/read/20180116/251/726682/ pengembangan-perikanan-bangun-ekonomimaritim-dari-natuna, diakses tanggal 8 Februari 2019.

${ }^{11}$ Anonim. "Ini Cara Jitu KKP Bantu Nelayan Natuna, Termasuk Memberi 60 Kapal" dalam
Sentuhan pembangunan oleh Kementerian Perikanan dan Kelautan ini cukup dirasakan oleh masyarakat. Hal ini ditunjukkan dengan ungkapan-ungkapan di masyarakat, khususnya para nelayan, bahwa dahulu Natuna tidak dikenal oleh orang Indonesia pada umumnya. Akan tetapi setelah Menteri Kelautan dan Perikanan sering melakukan kunjungan kerja, Natuna pun menjadi semakin terkenal. Terutama potensi di bidang kemaritimannya (Wawancara dengan Arrofik, 19 November 2017).

Pembangunan yang ditangani oleh Kementerian Pertahanan dan Keamanan dilakukan dengan pertimbangan bahwa Kabupaten Natuna merupakan wilayah terdepan dan terluar dari Republik Indonesia, sehingga rawan terhadap gangguan keamanan dan wilayah pertahanan terhadap penyusupan dari negara-negara lain, seperti: Tiongkok, Vietnam, Thailand, dan Malaysia.TerlebihTiongkok yang merasa menguasai wilayah Laut Cina Selatan, yang sebagian wilayahnya menjadi bagian dari NKRI.

Dengan pertimbangan tersebut, Pemerintah RI melalui Kementerian Pertahanan dan Keamanan akan menjadikan wilayah Natuna sebagai pusat kekuatan militer, dengan membangun pangkalan militer dan infra struktur militer, serta menempatkan pasukan TNI dalam jumlah yang cukup besar. Tujuannya adalah untuk mengamankan dan menjaga wilayah kedaulatan NKRI. ${ }^{12}$

https://www.merdeka.com/uang/ini-cara-jitukkp-bantu-nelayan-natuna-termasuk-memberi60-kapal.html, diakses tanggal 8 Februari 2019.

\footnotetext{
${ }^{12}$ Kemenhan. "Menhan: Pemerintahakan Bangun Pangkalan Militer Terbesar di Natuna" dalam

https://www.kemhan.go.id/itjen/2017/03/10/me nhan-pemerintah-akan-bangun-pangkalanmiliter-terbesar-di-natuna-2.html, diakses tanggal 8 Februari 2019.
} 
Saat ini Kementerian Pertahanan dan Keamanan melakukan sejumlah pembangunan sarana dan prasarana pertahanan negara, antara lain: Pembangunan pelebaran landasan pacu (runway) Bandara R. Sajad di Ranai, sehingga dapat didarati oleh dua pesawat tempur sekaligus; Perluasan Dermaga Penagi dan Dermaga Sebang, sehingga dapat digunakan untuk berlabuh kapalkapal perang. Selain itu, juga akan mendatangkan pasukan TNI dalam jumlah yang cukup banyak, yakni sekitar 15 personil, sehingga perlu dibangun penambahan akomodasi untuk menampung para prajurit TNI. ${ }^{13}$

Pembangunan yang ditangani oleh Kementerian Pariwisata dilakukan dengan pertimbangan bahwa wilayah Kabupaten Natuna memiliki banyak tempat yang indah dan dapat dikembangkan sebagai destinasi wisata, seperti: pantai, air terjun, bangunan monumental, dan pulau-pulau kecil. Ada 11 lokasi yang akan dikembangkan sebagai destinasi wisata, yang mengusung konsep marine, ecology, and archaeology (MEA). ${ }^{14}$

Selain itu, salah satu upaya untuk mempromosikan pariwisata Kabupaten Natuna adalah dengan penyelenggaraan Festival Senua 2018 pada tanggal 24 Juni 2018. Festival ini berhasil mendatangkan ribuan wisatawan, baik wisatawan mancanegara maupun wisatawan

\footnotetext{
${ }^{13}$ Kemenhan. "Kemenhan Bangun Sarana dan Prasarana Pertahanan di PulauNatuna" dalam https://www.kemhan. go.id/2017/03/08/kemhan-bangun-sarana-danprasarana-pertahanan-di-pulau-natuna.html, diakses tanggal 8 Februari 2019.

${ }^{14}$ Y. Gustaman. 2017. Pariwisata di Kabupaten Natuna Tertinggal, Begin iRespon PLN. Kamis, 19 Oktober 2017. http://www.tribunnews.com/bisnis/2017/10/19/ pariwisata-di-kabupaten-natuna-tertinggalbegini-respon-pln?page $=2$. diakses tanggal 8 Februari 2019.
}

nusantara. ${ }^{15}$ Upaya pengembangan sektor pariwisata di Kabupaten Natuna dilakukan karena saat ini masih tertinggal dibandingkan dengan kabupaten-kabupaten lain di Provinsi Kepulauan Riau.

Perairan Natuna juga dikenal sebagai wilayah yang kaya akan minyak dan gas bumi. Oleh karena itu Kementerian Energi dan Sumber Daya Mineral (ESDM) akan mengembangkan produksi minyak dan gas bumi di perairan tersebut, khususnya di Blok East Natuna. Kebijakan ini didorong oleh Ikatan Ahli Teknik Perminyakan Indonesia (IATMI), yang menginginkan agar pengembangan gas bumi di East Natuna dapat segera terealisir. ${ }^{16}$ Blok East Natuna tersebut ditemukan pada tahun 1973 dan diperkirakan memiliki sumberdaya sekitar 222 cadangan trillion standard cubic feet (TCF), dengan sumber daya kontijen sebesar 47 TCF. Sumberdaya sebesar itu merupakan cadangan gas terbesar di Indonesia. Meskipun demikian, pengembangan gas di Natuna belum terealisir hingga sekarang karena mengalami berbagai kendala yang selama bertahun-tahun belum berhasil diselesaikan oleh pemerintah, sementara permintaan gas semakin meningkat. ${ }^{17}$

\footnotetext{
${ }^{15}$ Anonim. "Siaran Pers: Festival Senua 2018 Promosikan Pariwisata Kabupaten Natuna" dalam $h t t p: / / w w w$. kemenpar.go.id/asp/detil.asp? $c=16 \& i d=4365$, diunduh tanggal 8 Februari 2019.

${ }^{16}$ Ahmad DwiAfriyadi. 2018. Dorong Pengembangan Gas Natuna, Para Ahli Migas Siap Kumpul Bareng. Senin, 10 September 2018. Juli 2018.

https://finance.detik.com/energi/d4204863/dorong-pengembangan-gas-natunapara-ahli-migas-siap-kumpul-bareng, diakses tanggal 8 Februari 2019.

${ }^{17}$ Ahmad Dwi Afriyadi. 2018. Dorong Pengembangan Gas Natuna, Para Ahli Migas Siap Kumpul Bareng. Senin, 10 September 2018. Juli 2018.

https://finance.detik.com/energi/d4204863/dorong-pengembangan-gas-natuna-
} 
Lalu yang menjadi pertanyaan, apa manfaat eksplorasi dan eksploitasi Lapangan East Natuna tersebut bagi masyarakat Natuna itu sendiri? Menurut Annisa Purwatiningsih dan Masykur, keberadaan Blok East Natuna secara tidak langsung memberikan kesejahteraan bagi masyarakat Natuna, yakni:

a. Membuka keterisoliran Kepulauan Natuna sebagai kawasan terpencil, sehingga sebagai implikasinya akan memicu mobilitas penduduk kekawasan pesisir di sekitar lokasi kegiatan eksploitasi migas untuk mencari penghidupan yang lebih baik.

b. Menyediakan lapangan kerja dan mengurangi pengangguran yang menjadi masalah serius karena pertumbuhan ekonomi yang hanya $4 \%$.

c. Peningkatan kehidupan sosial dengan adanya program pemberdayaan masyarakat (community development).

d. Partisipasi masyarakat untuk menggerakkan ekonomi kerakyatan, yaitu sebagai pemasok kebutuhan pokok di sekitar tempat kegiatan.

e. Terbangunnya infrastruktur untuk memicu roda perekonomian berbasis kerakyatan.

f. Kontribusi ekploitasi migas Natuna ke APBD Kabupaten Natuna dapat digunakan untuk pembangunan Kabupaten Natuna.

(Purwatiningsih dan Masykur, 2012: 64$65)$.

Adapun Kementerian Kehutanan dan Lingkungan Hidup berperan melakukan kajian dan evaluasi mengenai dampak pembangunan terhadap aspek lingkungan dan masyarakat di Kabupaten Natuna. Misalnya: melakukan kajian dampak lingkungan terhadap penggunaan kabel optik dalam program pembangunan Palapa Ring Barat $(\mathrm{PRB})^{18}$ dan rencana ekspor

para-ahli-migas-siap-kumpul-bareng, diakses tanggal 8 Februari 2019.

18 Diskominfo Natuna. "Kemen LHK Gelar Rapat Penilaian DELH" dalam

https://www.haluankepri. ikan napoleon (Cheilinus undulates) yang merupakan salah satu jenis ikan tangkapan para nelayan Natuna. ${ }^{19}$ Dalam hal ini kajian terhadap rencana ekspor ikan napoleon tersebut dimaksudkan untuk menjaga keberlangsungan dan kelestarian jenis ikan tersebut.

\section{PENUTUP}

Kabupaten Natuna, Provinsi Kepulauan Riau merupakan salah satu wilayah kepulauan terluar dari NKRI, sehingga dianggap mempunyai potensi disintegrasi. Terlebih lagi, Malaysia pernah menggugat kepemilikan Indonesia atas wilayah Kepulauan Natuna dengan menggunakan alasan kedekatan geografis maupun sejarah. Merunut sejarahnya, Kepulauan Natuna pernah menjadi bagian dari Kesultanan Johor sejak 1597, yang sekarang termasuk dalam wilayah Malaysia. Secara geografis, Kepulauan Natuna lebih dekat dengan Malaysia daripada Indonesia. Hal ini menyebabkan interaksi ekonomi dan sosial budaya masyarakatnya lebih dekat dengan Malaysia.

Sebagai wilayah yang secara geografis, ekonomi, dan sosial budaya dekat dengan Malaysia, ternyata tidak menyebabkan rasa nasionalisme masyarakat Natuna rendah dan berkeinginan disintegrasi dari Indonesia kemudian bergabung dengan Malaysia. Hal ini disebabkan oleh cara pandang masyarakat Natuna terhadap Indonesia. Bagi mereka, Indonesia adalah sebuah negara besar dengan wilayah yang jauh lebih luas dan jumlah penduduk jauh lebih

com/news/detail/109824/kemen-lhk-gelarrapat-penilaian-delh,diakses tanggal 8 Februari 2019.

${ }^{19}$ Anonim. "Ekspor Perdana Ikan Napoleon di Natuna" dalam http://www.menlhk. go.id/berita-10086-ekspor-perdana-ikannapoleon-di-natuna.html, diakses tanggal 18 Februari 2019. 
banyak daripada Malaysia. Selain itu, pada awal kemerdekaannya, Indonesia dipandang sebagai negara yang disegani oleh negara-negara lain di kawasan Asia.

Ditilik dari nasionalisme sebagai fenomena budaya, maka baik ketika masih menjadi bagian dari wilayah Kesultanan Johor maupun saat menjadi wilayah Kesultanan Riau, keduanya membawa etnisitas budaya Kemelayuan. Hal ini menyebabkan masyarakat Natuna tidak terlalu terikat secara budaya dengan masyarakat di Kesultanan Johor di Malaysia. Berdasarkan alasan tersebut, maka potensi disintegrasi pada masyarakat Natuna dapat dikatakan rendah.

Ditilik dari bentuk nasionalismenya, masyarakat Natuna termasuk dalam bentuk nasionalisme kenegaraan, yang merupakan kombinasi antara kewarganegaraan dengan etnisitas. Secara kewarganegaraan, masyarakat Natuna adalah bagian dari warga negara Indonesia. Secara etnisitas, sebagian besar masyarakat Natuna adalah etnis Melayu. Etnis Melayu tersebar baik di Indonesia, Malaysia, Singapura, maupun Brunei Darussalam. Dengan demikian, rasa nasionalisme masyarakat cukup kuat karena ikatan etnisitas mereka tidak dibatasi satu negara saja.

Meskipun demikian, apabila pemerintah kurang memperhatikan kesejahteraan masyarakat Natuna, sehingga tertinggal dengan daerah-daerah lainnya, maka potensi disintegrasi tersebut dapat meningkat dan mengancam keutuhan wilayah NKRI. Oleh karena itu, pada saat ini pemerintah telah mengupayakan pembangunan di Kabupaten Natuna. Terdapat lima kementerian yang mendapat prioritas untuk menangani pembangunan di Kabupaten Natuna, yakni: Perikanan dan Kelautan, Pertahanan dan Keamanan, Pariwisata, Kehutanan dan Lingkungan Hidup, serta Energi dan Sumber Daya Mineral. Dengan sentuhan pembangunan di Kabupaten Natuna tersebut, diharapkan akan meminimalisir potensi disintegrasi dan sekaligus meningkatkan rasa nasionalisme pada masyarakat Kabupaten Natuna.

\section{DAFTAR SUMBER}

\section{Jurnal, Makalah, dan Laporan Penelitian}

Hensel, Paul R., Michael E, Allison, and Ahmed Khanani. "Territorial Integrity Treaties, UtiPossidetis, and Armed Conflict over Territory". Makalah dalam Sambaugh Conference Building Synergies: Institution and Cooperation in World Politics. University of Iowa, 13 Oktober 2006.

Mezerik, Avrahm. "Malaysia Says Bloody Revolution Not Only Way to Independence". Malaysia-Indonesia Conflict: Creation of Malaysia, Indonesia's Confrontation Policy, Philippine and Indonesian Claims, UN Involvement, Indonesian Withdrawal from UN, roles of UK, US, USSR, and China. University of Michigan Press, International Review Service. Hlm. 108122.

Pamungkas, Cahyo. "Nasionalisme Masyarakat di Perbatasan Laut: Studi Kasus Masyarakat Melayu-Karimun" dalam Masyarakat Indonesia, Vol. 41 No. 2, Desember 2015. Jakarta: Lembaga Ilmu Pengetahuan Indonesia. Hlm. 147-162.

Purwatiningsih, Annisa., dan Masykur. "Eksplorasi dan Eksploitasi Pertambangan Minyak dan Gas Bumi di Laut Natuna Bagian Utara Laut Yuridiksi Nasional untuk Meningkatkan Kesejahteraan Masyarakat di Kepulauan Natuna" dalam Jurnal Reformasi, Volume 2, Nomor 2, Juli-Desember 2012. Hlm. 59-67.

Susilowati, Endang., Dhanang Respati Puguh, Noor Naelil Masruroh. "Penanaman Nilai-Nilai Nasionalisme pada Generasi Muda di Kepulauan Natuna" dalam Humanika, Vol. 19, No. 1 tahun 2014. Hlm. 158-170.

Susilowati, Endang. dan Noor Naelil Masruroh. "Merawat Kebhinekaan Menjaga Keindonesiaan: Belajar dari Nilai Keberagaman dan Kebersatuan Masyarakat Pulau" dalam Jurnal 
Sejarah Citra Lekha, Vol. 3, No. 1, 2018. Hlm. 13-19.

Tampi, Butje. "Konflik Kepulauan Natuna antara Indonesia dengan China (Suatu Kajian Yuridis)" dalam Jurnal Hukum Unsrat. Vol. 23 No. 10, Juli-Desember 2017. Hlm. 1-16.

\section{Buku}

Anderson, B., 1991.

Imagined Communities: Reflection on The Origin and Spread of Nationalism. London: Verso.

Bachtiar, Harsja W. 1997.

"Pengamatan sebagai Suatu Metode Penelitian" (Ed.) Koentjaraningrat. Metode-Metode Penelitian Masyarakat. edisi ketiga, Jakarta: Gramedia Pustaka Utama.

Badan Pusat Statistik Kabupaten Natuna. 2017. Kabupaten Natuna dalam Angka 2017. Ranai: Natuna.

Creswell, John W. 1994.

Research Design, Quantitative and Qualitative Approaches. Sage Publications. Inc.

Hutchinson, John. and Anthony D. Smith, (ed). 2000.

Nationalism: Critical Concepts in Political Science. London: Routledge.

Listiyarti, Retno. 2007.

Pendidikan Kewarganegaraan. Jakarta: Gelora Aksara Pratama

Martono, Nanang. 2016. Metode Penelitian Sosial, Konsep-Konsep Kunci. Cetakan kedua. Jakarta: Raja GrafindoPersada.

Nainggolan, P. P (eds.). 2004.

Batas Wilayah dan Situasi Perbatasan Indonesia: Ancaman terhadap Integritas Teritorial. Jakarta: Tiga Putra Utama.

Neuman, W. Lawrence. 2006. Social Research Method: Qualitative and Quantitative Approaches. Boston: Pearson Education Inc.

Nuraini. 2008.

$\begin{array}{lcr}\text { Sejarah } & \text { Terbentuknya Kabupaten } \\ \text { Natuna. } & \text { Tanjungpinang: } & \text { Balai } \\ \text { Pelestarian } & \text { Sejarah dan } & \text { Nilai }\end{array}$

Tradisional. Kementerian Kebudayaan dan Pariwisata.

Tim Penyusun Kamus Pusat Pembinaan dan Pengembangan Bahasa. 1990. Kamus Besar Bahasa Indonesia. Cetakan ketiga. Jakarta: Bala Pustaka, Departemen Pendidikan dan Kebudayaan.

Witton, Patrick. 2003. Indonesia. Lonely Planet.

\section{Sumber Lisan/Informan}

Amiruddin (51tahun). 2017. Pengajar pada Sekolah Tinggi Agama Islam Natuna.

Arrofik (35 tahun). 2017. Kepala Kantor Badan Karantina Laut dan Penjaminan Mutu Kabupaten Natuna.

\section{Website}

Afriyadi, Ahmad Dwi. "Dorong Pengembangan Gas Natuna, Para Ahli Migas Siap Kumpul Bareng" dalam https://finance.detik.com/ energi/d4204863/dorong-pengembangan-gasnatuna-para-ahli-migas-siap-kumpulbareng, diakses tanggal 8 Februari 2019.

Anonim. "Ini Cara Jitu KKP Bantu Nelayan Natuna, Termasuk Memberi 60 Kapal” dalam https://www.merdeka.com/uang/inicara-jitu-kkp-bantu-nelayan-natunatermasuk-memberi-60-kapal.html, diakses tanggal 8 Februari 2019.

Anonim. "Ekspor Perdana Ikan Napoleon di Natuna" dalam http://www.menlhk. go.id/berita-10086-ekspor-perdanaikan-napoleon-di-natuna.html, diakses tanggal 18 Februari 2019.

Anonim. "Siaran Pers: Festival Senua 2018 Promosikan Pariwisata Kabupaten Natuna" dalam http://www. kemenpar.go.id/asp/detil.asp? $c=16 \& i d=$ 4365, diunduh tanggal 8 Februari 2019.

Anonim. "Peta Malaysia" dalam https://www. romadecade. org/peta-malaysia/\#! diakses 27 Oktober 2018.

Anonim. "Luas Wilayah Indonesia" dalam https://www.scribd. 
com/doc/111362334/Luas-WilayahIndonesia, diakses tanggal 27 Oktober 2018.

Diskominfo Natuna. "Kemen LHK Gelar Rapat Penilaian DELH" dalam https://www.haluankepri. com/news/detail/109824/kemen-lhkgelar-rapat-penilaian-delh, diakses tanggal 8 Februari 2019.

Gustaman. Y. "Pariwisata di Kabupaten Natuna Tertinggal, Begini Respon PLN" dalam http://www.tribunnews.com/ bisnis/2017/10/19/pariwisata-dikabupaten-natuna-tertinggal-beginirespon-pln?page $=2$ diakses tanggal 8 Februari 2019.

Kamal, Mustafa. 2014. "Malaysia Inginkan Kepulauan Natuna Menjadi Wilayahnya." dalam https://www.kompasiana.com/alchemist/ malaysia-inginkan-kep-natuna-menjadiwilayahnya_ 54f7bc7ba333112b6f8b4cc7, diakses tanggal 27 November 2017.

Kemenhan. "Menhan: Pemerintahan Bangun Pangkalan Militer Terbesar di Natuna" dalam https://www.kemhan.go.id/itjen/2017/03/ 10/menhan-pemerintah-akan-bangunpangkalan-militer-terbesar-di-natuna2.html, diakses tanggal 8 Februari 2019.

Kemenhan. "Kemenhan Bangun Sarana dan Prasarana Pertahanan di PulauNatuna" dalam https://www.kemhan. go.id/2017/03/08/kemhan-bangunsarana-dan-prasarana-pertahanan-dipulau-natuna.html, diakses tanggal 8 Februari 2019.

Trisna, Yuri B. "Pulau Subi, Pusat Pertahanan Udara Jepang di Natuna" dalam https://pelantar.id/berita/kepriraya/natuna/pulau-subi-pusatpertahanan-udara-jepang-di-natunal, diakses 25 Februari 2019.

Vero, Adit. "Bupati Natuna Memakai Program Lima Pilar dalam Percepatan Pembangunan Daerahnya" dalam https://www. wartakepri.co.id/2018/01/24/bupatinatuna-memakai-program-lima-pilardalam-percepatan-pembangunan- daerahnya/, diakses tanggal 18 Februari 2019.

Widjaja, Sjarief. "Pengembangan Perikanan: Bangun Ekonomi Maritim dari Natuna" dalam https:// kalimantan.bisnis. com/read/20180116/251/726682/ pengembangan-perikanan-bangunekonomi-maritim-dari-natuna, diakses tanggal 8 Februari 2019. 